\title{
Interactive effect of biocontrol agents in the management of Fusarium rot in cardamom and its impact on plant defense mechanism
}

\author{
K C Veny Krishna ${ }^{1 *}$, M K Dhanya ${ }^{2}$, M Joy ${ }^{1}$, N S Radhika ${ }^{1} \&$ B Aparna ${ }^{3}$ \\ ${ }^{1}$ Department Plant Pathology, College of Agriculture, Vellayani, Thiruvananthapuram, 695 522, Kerala, India \\ ${ }^{2}$ Cardamom research station, Kerala Agricultural University, Pampadumpara, Idukki, 685 553, Kerala, India \\ ${ }^{3}$ Department of Soil Science and Agricultural Chemistry, College of Agriculture, Vellayani, Thiruvananthapuram, \\ 695 522, Kerala, India
}

"E-mail: krishnaveny98@gmail.com

Received 30 December 2020; Revised 24 April 2021; Accepted 26 April 2021

\begin{abstract}
Cardamom plantations are subjected to constant threat due to the Fusarium rot disease caused by Fusarium oxysporum Schlecht which is pronounced during summer months. The current study deals with the identification of an effective and ecofriendly management practice for the disease through the use of biocontrol agents. Survey conducted between February and May 2019 revealed maximum disease severity and incidence in Pampadumpara panchayat of Nedumkandam block $(84.40 \%$ and $100 \%)$ and minimum in Erattayar panchayat of Kattappana block $(50.40 \%$ and $60.00 \%)$. A pot culture experiment was conducted to study the effect of three bioagents (Glomus fasciculatum, Trichoderma asperellum and Pseudomonas fluorescens) individually as well as in combinations. Root inoculation of $G$. fasciculatum with basal application and spray with $P$. fluorescens as well as root inoculation of $G$. fasciculatum along with basal application of T. asperellum and P. fluorescens spray were identified to be effective against the disease. Disease suppression by the above bioagents was facilitated by reduced pathogen antagonist ratio in the soil, high level of mycorrhizal colonization in the roots and enhanced biochemical activity of defense enzymes like peroxidase, poly phenol oxidase and phenylalanine ammonia lyase in the plants.
\end{abstract}

Keywords: cardamom, defense enzymes, G. fasciculatum, F. oxysporum, P. fluorescens, T. asperellum

\section{Introduction}

Cardamom, commonly referred to as the "queen of spices", is one of the most valued spice crops in the world. In India, Kerala's western ghats is the main production home of this crop. Sustainable cardamom production has been challenged by several diseases that cause quantitative and qualitative crop loss. Fusarium rot caused by Fusarium oxysporum Schlecht is one of the most widespread and important fungal diseases of small cardamom 
(Thomas \& Vijayan 2002). The disease may become destructive at all growth stages of the crop under favorable weather conditions (mainly during summer season) as well as in the changing climatic scenario. Dhanya et al. (2018) reported that yield loss in poorly managed plantations accounts to about 50 per cent due to this disease. The pathogen's capability to survive in the soil and crop residues makes it very difficult to manage.

Murugan et al. (2016) reported that cardamom plantations in southern India have been receiving heavy doses of chemical pesticides due to which the pesticide consumption of the crop has increased by several folds during the last 50 years. In Kerala, an array of pesticides are banned due to various issues that arose due to their injudicious use. The recent trend is to encourage organic cultivation of cardamom for various reasons including environmental and health perspectives. Nowadays farmers are using different bio-agents and various organic inputs individually and in combinations for the management of Fusarium rot. In addition to disease management, good vegetative growth and yield were obtained from plantations that follow organic management practices against Fusarium rot in cardamom (Dhanya et al. 2018).

However, studies on individual and interactive effect of bioagents and their mode of action in the management of cardamom diseases are lacking. Considering this, the present work was carried out to identify an effective management practice against Fusarium rot of cardamom and to study its impact on pathogen antagonist ratio in soil, per cent mycorrhizal colonization in roots and biochemical defense mechanisms in plants.

\section{Materials and methods}

Surveys were carried out during February May of 2019 in two blocks of Idukki district, where cardamom cultivation is more prevalent. Based on this, three plantations each from Pampadumpara and Erattayar panchayats of Nedumkandam and Kattappana blocks respectively were identified as hotspot area for the disease. Each plantation was divided into four plots each with 250 plants. Twenty five plants were selected from each plot for the study. Five tillers, randomly selected from each plant, were subsequently scored for the disease using the score chart developed by Dhanya et al. (2018). The disease severity was worked out as per the method described by Singh (2002).

\section{Isolation of the pathogen}

The pathogen was isolated from infected panicles and pseudostem by adopting standard procedures. The pathogenicity was confirmed under greenhouse conditions.

\section{Pot culture experiment}

Cardamom suckers were raised in pots $(10 \mathrm{Kg}$ capacity) filled with solarised soil. Vermiculite based inoculum of G. fasciculatum (Kerala Agricultural University strain) was applied to the root zone at the time of planting. All the other treatments including chemical check were applied to the soil after the establishment of plants (one month after planting) in the pots. First spraying of the treatments (T4-T7) was given along with soil application and repeated at monthly intervals two times (Table 1). Three weeks after soil application of the treatments, pathogen innoculum (cfu $2 \times 10^{6} \mathrm{~g}^{-1}$ ) multiplied in sterilized sand maize medium prepared in the ratio 9:1 was applied to the base of all experimental plants @ 0.5 per cent pot ${ }^{-1}$.

The disease severity in the experimental plants in response to above treatments was recorded with a $0-4$ scale score chart.

0 - No disease

$1-1-10 \%$ area of the tillers had fungal lesions

$2-11-25 \%$ area of the of tiller had fungal lesions

3 - Root tip rotting as well as fungal lesions on $26-50 \%$ area of the of tiller

4 - Lesions on $>50 \%$ area of tiller as well as root rotting/ broken tillers at the point of infection 
Table 1. Treatment details of pot trial to manage Fusarium rot of cardamom

\begin{tabular}{|c|c|c|}
\hline Treatment & Basal application & Spraying (3 times) \\
\hline $\mathrm{T} 1$ & $\begin{array}{l}\text { G. fasciculatum @ } 2 \% \text { pot }^{-1} \text { to the root zone } \\
\text { at the time of planting }\end{array}$ & - \\
\hline $\mathrm{T} 2$ & $\begin{array}{l}\text { T. asperellum (KAU strain) in neem cake FYM mixture } \\
@ 1 \% \text { pot }^{-1}\end{array}$ & - \\
\hline T3 & $\begin{array}{l}\text { P. fluorescens (KAU strain) in cowdung slurry @ 2\% } \\
\text { pot }^{-1} \text { ) }\end{array}$ & - \\
\hline $\mathrm{T} 4$ & G. fasciculatum $\left(2 \% \operatorname{pot}^{-1}\right)$ & P. fluorescens (2\%) @ 0.5 L plant $^{-1}$ \\
\hline T5 & $\begin{array}{l}\text { G. fasciculatum }(2 \%)+T \text {. asperellum (enriched FYM } \\
\left.\text { mixture } @ 1 \% \text { pot }^{-1}\right)+P \text {. fluorescens }\left(2 \% \text { pot }^{-1}\right)\end{array}$ & P. fluorescens (2\%) @ 0.5 L plant ${ }^{-1}$ \\
\hline T6 & G. fasciculatum $(2 \%)+P$. fluorescens $\left(2 \%\right.$ pot $\left.^{-1}\right)$ & P. fluorescens (2\%) @ 0.5 L plant $^{-1}$ \\
\hline $\mathrm{T} 7$ & Carbendazim 50WP $\left(0.2 \%\right.$ pot $\left.^{-1}\right)$ & Carbendazim (0.1\%)@ 0.5 L plant ${ }^{-1}$ \\
\hline $\mathrm{T} 8$ & Control (untreated plants) & \\
\hline
\end{tabular}

Based on this, disease severity (PDI) was worked out using the formula described by Singh (2002)

Disease incidence (DI) was worked out as follows

\section{$\frac{\text { No. of plants infected }}{\text { Total number of plants observed }} \times 100$}

Population dynamics of Fusarium sp. and bio control agents in the soil

The population of the pathogen and biocontrol agents in soil was recorded one month after pathogen inoculation and repeated at monthly intervals two times using the serial dilution technique (Waksman 1922). The dilutions 10$3,10^{-4}$ and $10^{-6}$ were taken for enumeration of F. oxysporum and T. asperellum and P. fluorescens on Martin rose bengal agar (MRBA), Trichoderma specific media and Kings B media respectively.

Per cent colonization of arbuscular mycorrhizal fungi

Roots of cardamom plants inoculated with $G$. fasciculatum were collected at the end of the experiment and stained as per the protocol of Philip and Haymann (1970). The per cent colonization was worked out as follows.

$$
\begin{aligned}
& \text { No. of root bits having } \\
& \begin{array}{l}
\text { Per cent root } \\
\text { colonization }
\end{array}=\frac{\text { mycorrhizal colonization }}{\text { Total no. of root }} \times 100 \\
& \text { bits observed }
\end{aligned}
$$

Induction of defence enzymes in cardamom plants in response to bio control agents

Phenol (Bray \& Thrope 1954), OD phenol (Johnson \& Sachaal 1952), peroxidase (Srivastava 1987), polyphenol oxidase (Mayer \& Harel 1979) and phenylalanine ammonia lyase (Dickerson et al. 1984) were estimated from the leaves of treated plants as per the standard protocol at the end of the experiment.

\section{Results and Discussion}

Typical eye shaped lesions on the pseudostem and blighting of panicles were recorded from the surveyed plots with which the disease incidence and severity were worked out. These were reported to be the characteristic symptoms of $F$. oxysporum infection in cardamom (Vijayan et al. 2013, 2014). Disease 
incidence (\%) varied from 60-100 per cent and disease severity (\%) ranged from 50.4084.80 in the surveyed plants. Highest disease severity ( $84.80 \%)$ in Nedumkandam block was recorded from Pampadumpara panchayat and that in Kattappana block was from Erattayar panchayat $(77.40 \%)$. Thomas and Vijayan in a survey of 37 plantations of Idukki district during 2000-2002 observed DI ranging from 3-27.5\%. Further Vijayan et al. (2011) reported DI of 68 per cent during 2010-11.

Based on the pathogenicity test the pseudostem isolate $\left(\mathrm{Fs}_{1}\right)$ was found more virulent compared to panicle isolate $\left(\mathrm{Fp}_{1}\right)$. Therefore $\mathrm{Fs}_{1}$ was used in the pot culture studies. In the pot culture experiment, all the characteristic symptoms of the disease (root tip rot, foliar yellowing and pseudostem rot) were observed in the control plants. Disease severity was minimum in plants treated with the combination of $G$. fasciculatum, T. asperellum and P. fluorescens (T5 and T6) (Table 2). Yursan et al. (2009) noticed that disease severity of $F$. oxysporum Schlecht f. $\mathrm{sp}$ radicis-lycopersici in tomato was reduced
Table 2. Disease incidence and severity of cardamom plants inoculated with Fusarium sp. in response to treatments (pot culture)

\begin{tabular}{ccc}
\hline Treatment $^{*}$ & Disease incidence & $\begin{array}{c}\text { Disease } \\
\text { severity }\end{array}$ \\
\hline T1 & $88.83(100.00)$ & $39.23(40.00)$ \\
T2 & $46.43(52.50)$ & $32.89(30.00)$ \\
T3 & $55.25(67.66)$ & $37.75(37.50)$ \\
T4 & $43.56(47.50)$ & $31.60(27.50)$ \\
T5 & $39.81(41.00)$ & $24.67(17.50)$ \\
T6 & $36.27(35.33)$ & $24.26(17.00)$ \\
T7 & $40.10(41.50)$ & $29.88(25.00)$ \\
T8 & $88.34(100.00)$ & $69.38(87.50)$ \\
CD $(0.05)$ & 3.08 & 8.89 \\
C.V & 24.8 & 28.57 \\
\hline
\end{tabular}

*Details of treatments (T1 to $\mathrm{T} 8$ ) is provided in Table 1

(Values in parenthesis are Arc sine transformed)

significantly by the combined application of AMF and P. fluorescens. The present study also revealed that basal application of AMF with

Table 3. Population dynamics of Fusarium sp. and biocontrol agents in soil

\begin{tabular}{|c|c|c|c|c|c|c|c|c|c|}
\hline \multirow[t]{2}{*}{ Treatment* } & \multicolumn{3}{|c|}{$\begin{array}{l}\text { One month after pathogen } \\
\text { inoculation }\end{array}$} & \multicolumn{3}{|c|}{$\begin{array}{l}\text { Two months after pathogen } \\
\text { inoculation }\end{array}$} & \multicolumn{3}{|c|}{$\begin{array}{l}\text { Three months after } \\
\text { pathogen inoculation }\end{array}$} \\
\hline & 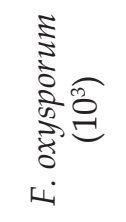 & 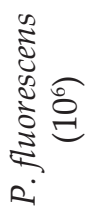 & 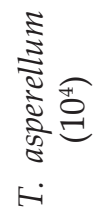 & 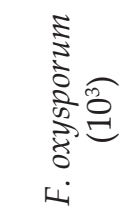 & 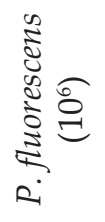 & 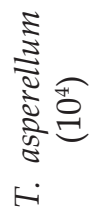 & 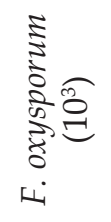 & 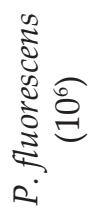 & 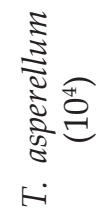 \\
\hline $\mathrm{T} 1$ & $16.50^{\mathrm{bc}}$ & - & - & $19.50^{a}$ & - & - & $8.50^{\mathrm{b}}$ & & \\
\hline $\mathrm{T} 2$ & $16.50^{\mathrm{bc}}$ & - & 8 & $15.50^{c}$ & - & 2.5 & $4.00^{\text {de }}$ & - & \\
\hline T3 & $15.00^{\mathrm{cd}}$ & 5 & - & $17.00^{\mathrm{b}}$ & 2 & - & $5.00 \mathrm{c}$ & 1 & - \\
\hline $\mathrm{T} 4$ & $16.00^{\mathrm{bc}}$ & 3 & - & $12.00^{\mathrm{d}}$ & 1 & - & $3.50^{\mathrm{ef}}$ & 1 & - \\
\hline T5 & $12.75^{\mathrm{d}}$ & 3 & 8 & $11.00^{\mathrm{de}}$ & 3 & 5.5 & $2.00^{\mathrm{f}}$ & 5 & 6 \\
\hline T6 & $15.00^{\mathrm{cd}}$ & 3 & - & $10.50^{c}$ & 4 & - & $2.00^{\mathrm{f}}$ & 6 & - \\
\hline $\mathrm{T} 7$ & $10.50^{\mathrm{e}}$ & - & - & $12.50^{\mathrm{d}}$ & - & - & $2.00^{\mathrm{f}}$ & - & - \\
\hline $\mathrm{T} 8$ & $19.00^{\mathrm{a}}$ & - & - & $20.50^{a}$ & - & - & $22.00^{\mathrm{a}}$ & - & - \\
\hline $\mathrm{CD}(0.05)$ & 1.67 & & & 2.73 & & & 1.16 & & \\
\hline
\end{tabular}

*Details of treatments (T1 to T8) is provided in Table 1 
either T. asperellum or $P$. fluorescens reduced the disease severity by 69.50 and 70.00 per cent respectively. Similar to this, Srivastava et al. (2010) observed that combined application of AMF, Trichoderma sp. and P. fluorescens was effective in reducing the Fusarium wilt of tomato (F. oxysporum f. sp. lycopersici) by 63.00 per cent. While conducting the compatibility studies between Trichoderma sp. and AMF, synergistic nature of these bioagents was confirmed by Camprubi et al. (1995). According to Mbuthia et al. (2019) the complimentary effect of the above bioagents in combination might be due to their additive or synergistic nature. Field study conducted by Dhanya et al. (2018) confirmed the effective role of bio agents like Trichoderma sp., P. fluorescens and AMF as combination against the Fusarium rot of cardamom. From the present study it was also concluded that root inoculation of G. fasciculatum along with P. fluorescens (as basal application and spray) (T6) are equally effective and statistically on par with the above treatment. The study also provides a clear cut idea about the effectiveness of the above bioagents in Fusarium rot management when used individually and in combination.

The pathogen - antagonist ratio in soil when treated with combinations of G. fasciculatum and T. asperellum as well as G. fasciculatum and $P$. fluorescens (Table 4) reduced considerably and became minimum in third analysis.

Table 4. Colonization per cent of AMF in cardamom roots when applied alone and in combination with $T$. asperellum and $P$. fluorescens

Treatment Colonization per cent

\begin{tabular}{llc}
\hline T1 & G. fasciculatum & 50.55 \\
T5 & $\begin{array}{l}\text { G. fasciculatum }+ \\
\text { T.asperellum }\end{array}$ & 68.76 \\
T6 & $\begin{array}{l}\text { G. fasciculatum }+ \\
\text { P. fluorescens }\end{array}$ & 80.00 \\
T9 & Control & 0.00 \\
\hline
\end{tabular}

Similar to this, Khan et al. (2004) reported a drastic reduction in the population of soil wilt pathogen (Fusarium oxysporum $\mathrm{f}$ sp. ciceri) when Trichoderma sp. was applied to chickpea plants. From the present study it was concluded that when the bioagents were used in combination, (i.e. G. fasciculatum with either T. asperellum or $P$. fluorescens) their interactive effect enhanced the population of both biocontrol agents in the soil (Table 3). Dehariya et al (2004) also reported that when AMF and Trichoderma sp were given in combination against Fusarium udum in pigeon pea, both AMF colonization in plant roots and Trichoderma population in soil were triggered. Sangeetha et al. (2013) reported high population of $P$. fluorescens in soil even after 75 days, if applied along with AMF compared to its sole application. All these research findings strongly support the results of the present study.

Root staining was done for the AMF treated plants at the end of the experiment and colonization was observed in all treated plants. Colonization percentage and number of vesicles were comparatively higher when AMF was given in combination either with T. asperellum or P. fluorescens (Fig.1). Sarma et al. (2014) opined that Trichoderma sp. induced an enhanced colonization of AMF in vascular plants which supports the present results. Boer et al. (2005) also reported 50$60 \%$ enhanced mycorrhizal colonization in roots when co-inoculated with $P$. fluorescens. Kumar et al. (2012) obtained similar results in sorghum. Gamalero et al. (2013) found significant colonization of AMF in tomato roots inoculated with $P$. fluorescens. Colonization per cent obtained by combined application of AMF with T. asperellum was $68.76 \%$ in the present study (Table 4). Yadav \& Aggarwal (2015) also reported similar result in ground nut. In the study, soil application of $G$. fasciculatum with $T$. asperellum and $P$. fluorescens resulted in $77.8 \%$ colonization of the roots. An evaluation study with different $P$. fluorescens strains and AMF strains in sorghum resulted in 50.90 to $72.80 \%$ colonization (Kumar et al. 2011).

AMF with T. asperellum and P. fluorescens 

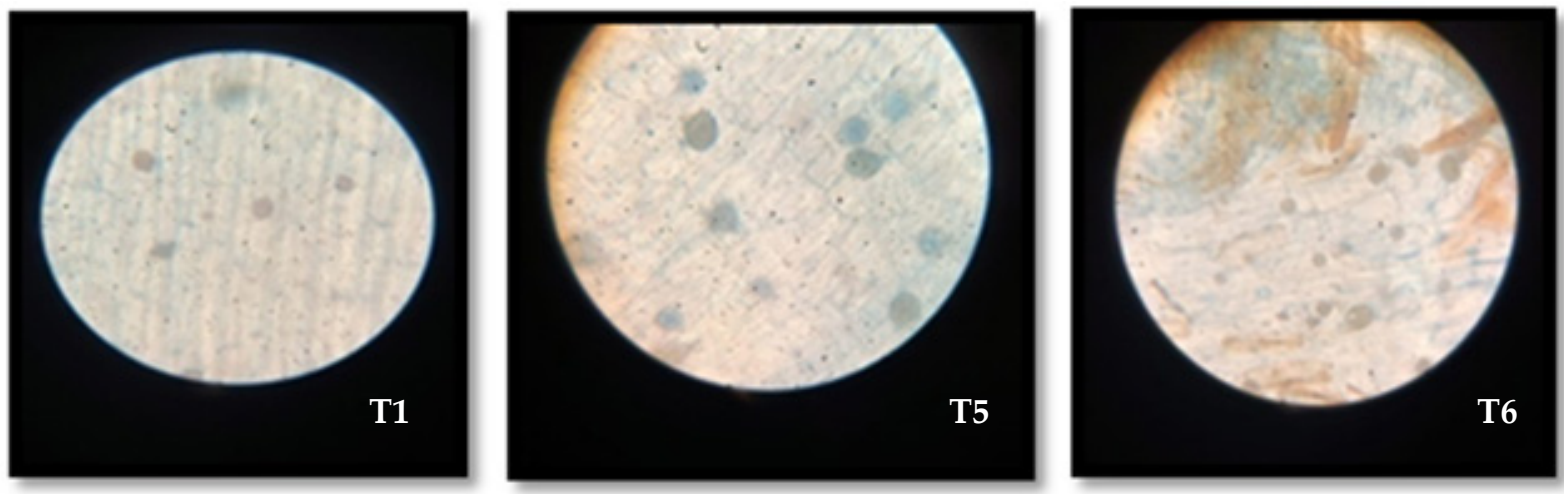

Fig 1. Root Colonization of G. fasciculatum in treatment plants

(T5) increased the level of defense related biochemical activities like phenol (7.05 $\left.\mu \mathrm{gl}^{-1}\right)$, OD phenol $\left(36.03 \mu \mathrm{gl}^{-1}\right)$, PO (30.82 $\left.\mu \mathrm{g} \min ^{-1} \mathrm{~g}^{-1}\right)$ and PPO (1.17 $\left.\mu \mathrm{g} \mathrm{min}^{-1} \mathrm{~g}^{-1}\right)$ in cardamom leaves three months after treatment (Table 5). Allay and Chakraborty (2013) reported induction of defence enzymes like $\beta-1,3$-glucanase and peroxidase in mandarin against $F$. solani by dual application of AMF and T. asperellum. Doley et al. (2014) also reported the role of $G$. fasciculatum and T. viride in managing Macrophomina phaseolina infection in ground nut through the induction of phenol, peroxidase and poly phenol oxidase. Duc et al. (2017) observed that, application of Trichoderma sp., AMF and P. fluorescens accelerated the activities of poly phenol oxidase in Kapria cultivar and peroxidase in Karpex cultivar of pepper. Basal application of G. fasciculatum and P. fluorescens along with $P$. fluorescens spray (T6) enhanced OD phenol

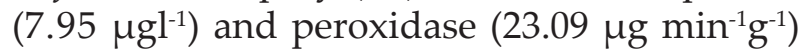
activities of cardamom leaves. Mohamed et al. (2019) observed high level of PO in common bean against Sclerotium rolfsi when treated with P. fluorescens and AMF. High concentration of OD phenol $(90.6 \mu \mathrm{g})$ was observed in Solanum viarum seedlings (Hemashenpagam and Selvaraj, 2011) when combined inoculation of AMF and T. harzianum was given. Sangeetha

Table 5. Estimation of biochemical parameters in cardamom plants subjected to different treatments

\begin{tabular}{cccccc}
\hline Treatment $^{*}$ & $\begin{array}{c}\text { Phenol } \\
\left(\mu \mathrm{gl}^{-1}\right)\end{array}$ & $\begin{array}{c}\text { OD-phenol } \\
\left(\mu \mathrm{gl}^{-1}\right)\end{array}$ & $\begin{array}{c}\mathrm{PO} \\
\left(\mu \mathrm{min}^{-1} \mathrm{~g}^{-1}\right)\end{array}$ & $\begin{array}{c}\text { PPO } \\
\left(\mu \mathrm{min}^{-1} \mathrm{~g}^{-1}\right)\end{array}$ & $\begin{array}{c}\text { PAL } \\
\left(\mu \mathrm{gmin}^{-1} \mathrm{~g}^{-1}\right)\end{array}$ \\
\hline T1 & 10.10 & 38.05 & 12.85 & 0.49 & 0.19 \\
T2 & 4.70 & 42.45 & 11.00 & 0.60 & 0.21 \\
T3 & 4.25 & 31.83 & 16.95 & 0.92 & 0.16 \\
T4 & 6.60 & 40.56 & 20.14 & 2.39 & 0.14 \\
T5 & 7.05 & 36.03 & 30.82 & 1.17 & 0.01 \\
T6 & 7.95 & 45.61 & 23.09 & 2.03 & 0.02 \\
T7 & 5.87 & 38.43 & 1.10 & 0.37 & 0.15 \\
T8 & 2.90 & 20.85 & 3.06 & 0.26 & 0.006 \\
CD (0.05) & 0.79 & 1.68 & 1.65 & 0.39 & 0.03 \\
CV & 17.12 & 16.08 & 6.70 & 23.03 & 19.71 \\
\hline
\end{tabular}

*Details of treatments is provided in Table 2 
et al. (2013) reported that treatment with AMF and Pseudomonas sp. induced good level of phenol on $75^{\text {th }}$ day of inoculation in maize. Therefore it is evident that combination of bioagents imparts good management of the disease through less pathogen antagonist ratio, increased root colonization by $G$. fasciculatum and activation of bio chemical defence mechanisms in plants.

\section{Acknowledgement}

The authors are grateful to Cardamom Research Station, Pampadumpara, Idukki and College of Agriculture, Vellayani, Thiruvananthapuram for providing the laboratory and field facilities. The authors are also thankful to KAU for the financial assistance given to carry out the research work.

\section{References}

Allay S \& Chakraborty B N 2013 Induction of resistance in Citrus reticulata against Fusarium solani by dual application of AMF and Trichoderma asperellum. Int. J. Bio-resourse Stress Manag. 4: 588-592.

Boer W D, Folman L B, Summerbell R C \& Boddy L 2005 Living in a fungal world: impact of fungi on soil bacterial niche development. FEMS microbial. Reviews 29: 795-811.

Bray G G \& Thrope W V 1954 Analysis of phenolic compounds of interest in metabolism. Methods Biochemical Anal.1: 27-52.

Camprubi A, Calvet C \& Estaun V 1995 Growth enhancement of Citrus reshmi after inoculation with Glomus intraradices and Trichoderma aureoviride and associated effects on microbial populations and enzyme activity in potting mixes. Plant Soil. 173: 233-238.

Dehariya K Shukla A, Ganaie M A \& Vyas D 2014 Individual and interactive role of Trichoderma and Mycorrhizae in controlling wilt disease and growth reduction in Cajanus cajan caused by Fusarium udum. Archives Phytopathol. Plant Prot. 48: 50-61.

Dhanya M K, Murugan M, Deepthy K B, Aswathy T S \& Sathyan T 2018 Management of Fusarium rot in small cardamom. Indian. J. Plant Prot. 46: 57-62.
Dickerson DP, PascholatiSF, Hangerman E A, Butler L G \& Nicholson R C 1984 Phenylalanine ammonia-lyases and hydroxycinnamate: CoA ligase in maize mesocotyls inoculated with Helminthosporium maydis or Helminthosporium carbonum. Physiol. Plant Pathol. 25: 111-123.

Doley K, Borde M, Dudhane M \& Jite P K. 2014. Efficiency of Glomus fasciculatum and Trichoderma viride in bio-control of soilborne pathogen (Macrophomina phaseolina) on different groundnut cultivars. Biosci. Discovery 5: 163-169.

Duc N H, Mayer Z, Pek Z, Helyes L \& Posta, K 2017 Combined inoculation of arbuscular mycorrhizal fungi, Pseudomonas fluorescens and Trichoderma spp. for enhancing defense enzymes and yield of three pepper cultivars. Appl. Ecol. Environ. Res. 15(3): 1815-1829.

Gamalero E, Trotta A, Massa N, Copetta A, Martinotti M G \& Berta G 2003 Impact of two fluorescent pseudomonads and an arbuscular mycorrhizal fungus on tomato plant growth, root architecture and $\mathrm{P}$ acquisition. Mycorrhiza 14: 185-192.

Gopi R, Avasthe R K, Kalitha H, Ashish Y, Chandan K, \& Chandan P 2016 A new record of Fusarium oxysporum causing stem lodging, inflorescence and capsule rot in large cardamom. Indian Phytopathol 69(3): 316-317.

Hemashenpagam N \& Selvaraj T 2011 Effect of arbuscular mycorrhizal (AM) fungus and plant growth promoting rhizomicroorganisms (PGPR's) on medicinal plant Solanum viarum seedlings. J. Environ. Biol. 32: 579-583

Johnson G \& Sachaal L A 1952 Chlorogenic acid and other ortho-dihydric phenols in scab resistant Russet Burbank and scab susceptible Triumph potato tubers of different maturities. Phytopathol. 47:253-258.

Khan M R, Khan S M \& Mohiddin F A 2004 Biological control of Fusarium wilt of chickpea through seed treatment with the commercial formulation of Trichoderma harzianum and/ or Pseudomonas fluorescens. Phytopathologia Mediterrane 43: 20-25.

Kumar G P, Kishore N, Amalraj E L D, Ahmed S K M H, Rasul A \& Desai S 2012 Evaluation of 
fluorescent Pseudomonas spp. with singleand multiple PGPR traits for plant growth promotion of sorghum in combination with AM fungi. Plant Growth Reg. 67: 133-140.

Kumar K, Xi K, Turkington T K, Tekauz A, Helm J H \& Tewari J P 2011 Evaluation of a detached leaf assay to measure fusarium head blight resistance components in barley. Can. J. Plant Pathol. 33: 364-374.

Mayer A M \& Harel E 1979 Polyphenol oxidase in plants. Phytochem. 18: 193-215.

Mbuthia L W, Kiirika L M, Afolayan G \& Henning V A 2019 Interactive effects of arbuscular mycorrhizal fungi Glomus intreradices and Trichoderma harzianum against Fusarium wilt of tomato. Int. J. Biosci. 15: 251-268.

Mohamed I, Eid K H, Abbas M H H, Salem A A, Ahmed N, Ali M, Shah G M \& Fang C 2019 Use of plant growth promoting rhizobacteria (PGPR) and mycorrhizae to improve the growth and nutrient utilization of common bean in a soil infected with white rot fungi. Ecotoxicol. Environ. Saf. 171: 539-548.

Murugan M, Dhanya M K, Deepthy K B, Preethy T T, Aswathy T S, Sathyan T \& Manoj V S. 2016. Compendium on Cardamom, Kerala Agricultural University, Cardamom Research Station, Pampadumpara, 66p.

Philip J M \& Hayman D 51970 Improved procedure for clearing roots and staining parasitic and vesicular- arbuscular mycorhizal fungi rapid assessment of infection. Tran. Br. Mycol. Soc. 158-161.

Sangeetha, J., Solomon, E K., Natarajan, K \& Rajeshkannan V 2013 Efficacy of AMF and PGPR inoculants on maize (Zea mays L.) plant growth and their rhizosphere soil properties. Microbiol. Res. Agroecosyst. Manag. 155-173.

Sarma B K, Yadav S K, Patel J S \& Singh H B 2014 Molecular mechanisms of interactions of Trichoderma with other fungal species. Open Mycol. J. 8: 140-147.

Singh RS 2002 Principles of Plant Pathology (4th Ed.). Oxford \& IBH Publishing Co. Pvt. Ltd., New Delhi, 385p.
Srivastava R, Khalid A, Singh U S \& Sharma A K 2010 Evaluation of arbuscular mycorrhizal fungus, fluorescent Pseudomonas and Trichoderma harzianum formulation against Fusarium oxysporum f. sp. lycopersici for the management of tomato wilt. Biol.Control 53:24-31.

Srivastava S K 1987 Peroxidase and polyphenol oxidase in Brassica juncea plant Infected with Macrophomina phaseolina (Tassi) Gold, and their implication in disease resistance. J. Phytopathol. 120 : 249-254.

Thomas J \& Vijayan A K 2002 Fusarium oxysporum, a new threat to cardamom cultivation. In: Sreedharan K, Kumar V P K, Jayarama \& Chulaki BM (Eds.) Proceedings of Plantation Crops Symposium Placrosym XV, 10-13 December 2002, Mysore (pp. 535-540). Central Coffee Research Institute, Mysore.

Vijayan A K, Francis S M \& Sudharshan M R 2014 Fusarium infections of small cardamom in the field and its management. J. Plant. Crops 42: 241-245.

Vijayan A K, Sithara L, Thomas J, Thomas J, Misra R S \& Saju K A 2013 Molecular characterization in small cardamom (Elettaria cardamomum Maton). Arch. Phytopathol. Plant Prot. 46: 1-8.

Waksman S A 1922 A method for counting the number of fungi in the soil. J. Bacteriol. 7(3): 339-341.

Yadav A \& Aggarwal A K 2015 Associative effect of arbuscular mycorrhizae with Trichoderma viride and Pseudomonas fluorescens in promoting growth, nutrient uptake and yield of Arachis hypogaea L. New York Sci. J. 8(1): 101-108.

Yursan, Roemheld Y, Mueller V \& Tosten 2009. Effects of Pseudomonas sp. "Proradix" and Bacillus amyloliquefaciens FZB42 on the Establishment of AMF Infection, Nutrient Acquisition and Growth of Tomato Affected by Fusarium oxysporum Schlecht f. sp. radicis-lycopersici Jarvis and Shoemaker. In: Davis U.C. (Eds.), The Proceedings of the International Plant Nutrition Colloquium XVI, 14 June 2009, California. Department of Plant Science. 